\title{
Apersepsi Guru dalam Pembelajaran Membaca Permulaan Bagi Anak Usia Dini
}

\author{
Gegana Jayapada ${ }^{1}$, Imam Suyitno ${ }^{1}$, Suyono ${ }^{1}$ \\ ${ }^{1}$ Pendidikan Bahasa Indonesia-Universitas Negeri Malang
}

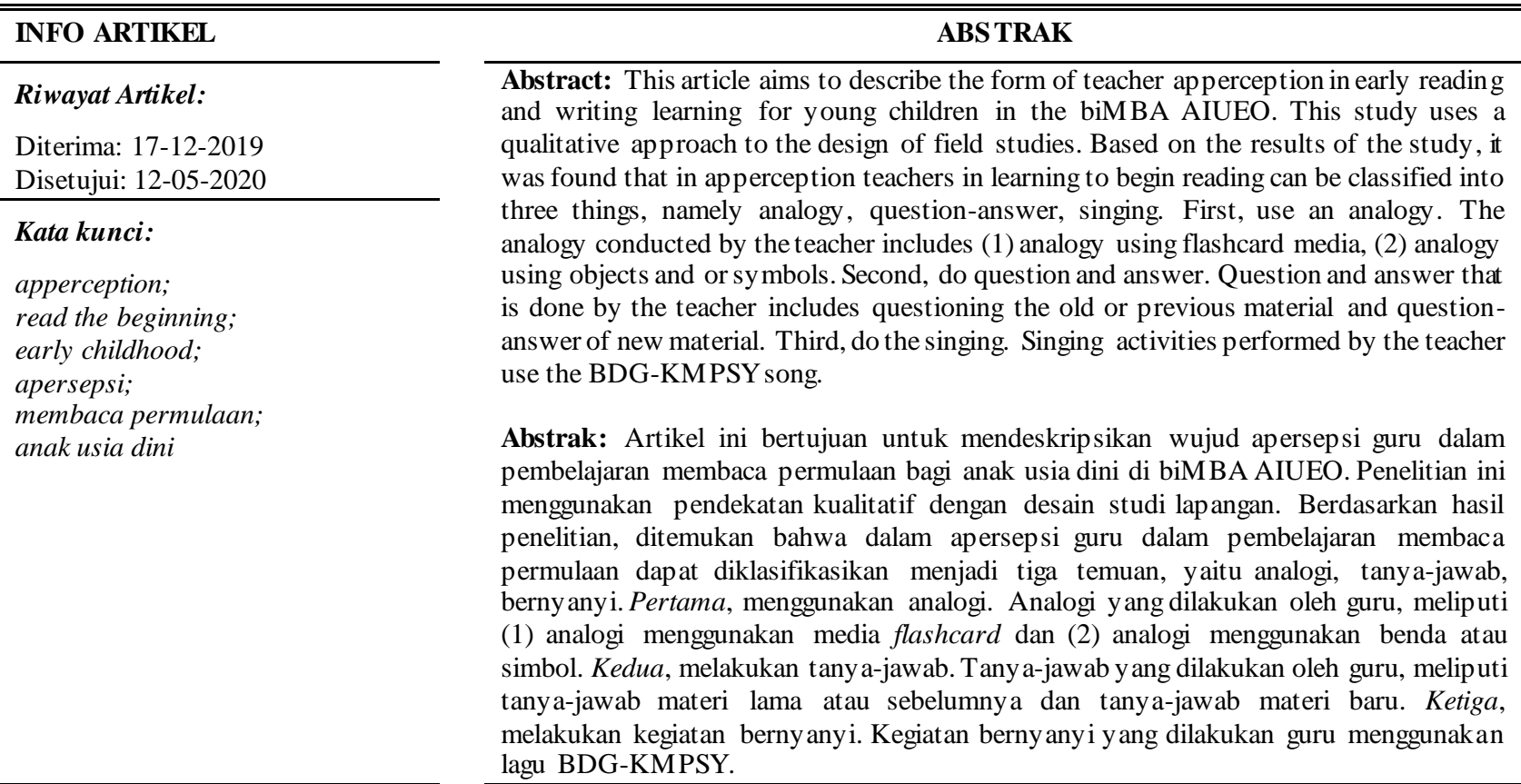

\section{Alamat Korespondensi:}

Gegana Jay apada

Pendidikan Bahasa Indonesia

Universitas Negeri Malang

Jalan Semarang 5 Malang

E-mail: geganajayapada@ gmail.com

Belajar adalah proses mengubah pikiran, pengetahuan dan perilaku siswa yang dilakukan oleh guru. Menurut Rahyubi (2012), belajar adalah perubahan pengetahuan atau kemahiran seseorang melalui rangkaian kegiatan atau pikiran secara sadar. Belajar juga dapat dimaknai sebagai proses mencari pengetahuan atau pengalaman. Dengan demikian, guru perlu menyiapkan pendekatan dan teknik yang efektif berdasarkan berbagai sumber (Lam, Cheng, \& Ma, 2009). Oleh karena itu, berbagai strategi atau metode dalam proses belajar-mengajar harus dilakukan oleh guru untuk memastikan bahwa materi pembelajaran dapat tersampaikan secara efektif kepada siswa sehingga tujuan pembelajaran dapat tercapai.

Siswa akan senang dengan proses pembelajaran apabila memiliki motivasi dan semangat dalam menyerap pengetahuan. Berbagai metode atau cara dalam proses belajar mengajar harus dialami oleh guru untuk memastikan bahwa pengetahuan dapat disampaikan secara efektif kepada siswa sehingga tujuan pembelajaran akan berhasil (Miller, 2003; Wilhelm \& Smith, 2006). Salah satu pendekatan untuk merangsang motivasi belajar siswa ialah apersepsi. Ningsih \& Mastuti(2013) menyatakan apersepsi dilakukan untuk menimbulkan perhatian dan memotivasi siswa yang tidak hanya dilakukan pada awal pembelajaran, namun dapat juga dilakukan pada awal atau setiap kegiatan inti pembelajaran. Bellucci (2015) apersepsi adalah interpretasi psikologis dari pikiran yang digabung dengan pengamatan dan pengalaman yang dimiliki oleh seseorang. Untuk itu, guru perlu memberikan apersepsi kepada siswa. Apersepsi penting dilakukan untuk pemahaman, peningkatan pengetahuan, dan peningkatan kemampuan para siswa (Brdar, Rijavec, \& Loncaric, 2006).

Apersepsipenting dilakukan guru sebelum tahap kegiatan inti pembelajaran sehingga siswa menjadi mantap menyerap pelajaran yang telah ditransfer. Memberikan persepsiadalah keterampilan khusus yang harus ada dipelajari oleh guru karena ketika para guru memasuki kelas untuk pertama kalinya akan menjadi penentu momen untuk tahap selanjutnya (Sugahara, Sugao, Dellaportas, \& Masaoka, 2016). Menit pertama dari proses pembelajaran adalah waktu vital yang menentukan kondisi belajar berikutnya (Brew \& Boud, 1995). Untuk itu, apersepsi tidak dapat terlewatkan begitu saja. Apersepsi penting dilakukan karena sebagai landasan bagi siswa untuk memahami hal baru. Apersepsi berfungsi untuk menyatupadukan dan mengasimilasi 
pengamatan dan pengalaman yang dimiliki oleh siswa. Oleh karena itu, apersepsi penting dilakukan guru dalam mepersiapkan siswa untuk mengikuti proses pembelajaran sehingga pembelajaran lebih optimal. Memberikan persepsi pada setiap awal pelajaran adalah penting untuk memastikan bahwa siswa siap menyerap pengetahuan belajar (Howard, 2002).

Apersepsi juga biasa disebut advance organizer. Palisoa (2008) advance organizer dirancang untuk memantapkan struktur kognitif siswa karena struktur kognitif merupakan faktor yang sangat menentukan kalau materi baru tersebut dapat diperoleh atau dipertahankan. Sehubungan dengan itu, pemberian apersepsi tentu akan menimbulkan dampak yang positif bagi siswa. Pemberian apersepsiberpengaruh positif terhadap kesiapan belajar dan nilai siswa. Apersepsipada kegiatan pendahuluan atau kegiatan awal perlu dilakukan untuk mengondisikan siswa dengan baik karena keadaan siswa akan memengaruhi proses belajar-mengajar hingga selesai (Ningsih \& Mastuti, 2013).

Apersepsi juga dapat dimaknai sebagai interpretasi. Etikawati (2017) menyatakan apersepsi adalah interpretasi yang dibentuk oleh pengalaman masa lalu bagi anak. Seorang anak dapat menginterpretasi kedua orangtuanya. Untukitu, hal ini dapat dijadikan landasan guru dalam mengajarkan membaca permulaan. Membaca permulaan bertujuan untuk mengenalkan konsep huruf maupun bunyi yang dilafalkan kepada anak. Churiyah (2013) menyatakan membaca permulaan bertujuan untuk membinakan dasar mekanisme membaca. Dasar mekanisme membaca ini, meliputi mengasosiasikan huruf dengan bunyinya, membina gerakan mata dan membaca kata-kata serta kalimat sederhana. Ikawati (2013) yang menyatakan untuk menumbuhkan kebiasaan membaca, waktu yang tepat untuk menumbuhkan kebiasaan membaca ialah ketika masa anak-anak. Kemampuan membaca penting sebagai dasarsupaya anak dapat mengikuti pembelajaran di jenjang SD. Akan tetapi, hal ini masih saja menjadi perdebatan tentang boleh-tidaknya anak usia dini belajar membaca. Menurut Asiah (2018) anak tidak harus diajarkan bisa bacatulis. Di sisi lain, Tajuddin (2018) membolehkan mengajar membaca pada anak asalkan dapat diberikan dengan kondisi yang menyenangkan dan bertujuan untuk menumbuhkan minat anak-anak dalam membaca. Dengan demikian, anak boleh belajar membaca, namun sebaiknya pada penumbuhan minat dan sebatas dikenalkan saja. Oleh karena itu, sebelum memasuki sekolah dasar, maka anak harus melalui keterampilan membaca dulu (Pertiwi, 2016).

Anak usia dini perlu mendapatkan bimbingan dalam belajar membaca agar siap ketika memasuki jenjang sekolah dasar. Belajar membaca permulaan meski sejak dini penting supaya anak memiliki bekal untuk belajar membaca lanjut. Pengembangan membaca permulaan adalah prediktor yang sangat kuat untuk pengembangan membaca lanjut dan sangat penting untuk keberhasilan akademik di masa mendatang (Juel, Hall, Leavell, \& Schneider, 1988; Stanovich, 1986). Melalui pemberian apresepsioleh guru, diharapkan dapat membantu siswa ketika belajar membaca permulaan. Dalam menyampaikan apersepsi, guru perlu memutuskan metode yang tepat untuk memastikan siswa memiliki motivasi belajar (Williams \& Stockdale, 2004).

Anak yang termotivasi akan dengan mudah mengikuti pembelajaran. Siswa yang selalu memperhatikan pelajaran atau pelajaran yang diberikan, tidak akan menjadi masalah bagi guru karena siswa sudah berhasil mengembangkan motivasi diri mereka yang dikenal dengan intrinsik motivasi (Mizuno, Tanaka, Fukuda, Imai-Matsumura, \& Watanabe, 2011). Dengan demikian, kondisi seperti itu tentu akan memudahkan guru ketika menyampaikan pembelajaran. Tujuan penelitian ini adalah mendeskripsikan wujud apersepsiguru dalam pembelajaran membaca permulaan bagi anak usia dini di biMBA AIUEO.

\section{METODE}

Penelitian ini menggunakan pendekatan kualitatif dengan jenis penelitian studi lapangan. Penelitian ini menggunakan pendekatan kualitatif karena setidaknya memiliki lima karakteristik, meliputi (1) latar alamiah, yaitu biMBA AIUEO, (2) peneliti sebagai instrumen kunci sehingga mengumpulkan data sendiri melalui pengamatan perilaku (3) data yang dikumpulkan berasal dari observasilangsung, dan (4) analisis data dilakukan secara induktif karena peneliti membangun pola partisipan, kategori, dan topik dari bawah ke atas, dengan mengatur data menjadi unit informasi yang semakin abstrak, dan (5) memaknai partisipan, karena dalam keseluruhan proses penelitian selalu fokus mempelajari makna partisipan.

Jenis penelitian yang digunakan ialah studi lapangan. Studi lapangan digunakan untuk mendeksripsikan informasi mengenai status suatu gejala yang ada di lokasi penelitian. Informasi yang dideskripsikan ialah wujud apersepsi guru dalam pembelajaran membaca permulaan bagi anak usia dini di biMBA AIUEO. Oleh karena itu, pendekatan kualitatif dengan jenis penelitian studi lapangan dianggap tepat merancang penelitian ini. Penelitian ini berlokasi di biMBA AIUEO unit Karangloland yang berlokasi di Perum Permata Karanglo Land Kavling 17, Jl Mondoroko Selatan, Karanglo, Banjararum, Singosari, Malang, Jawa Timur. Dalam pengumpulan data, digunakan instrumen tambahan untuk mendapatkan data sesuai fokus penelitian. Instrumen tersebut berupa alat perekam Canon Ixus 145. Selain perekam, catatan lapangan digunakan untuk mencatat hal-hal penting dan transkripsi percakapan yang terjadi di lapangan.

Data yang dikumpulkan berupa tuturan verbal dari guru dalam kegiatan apersepsi yang direkam langsung melalui alat perekam. Sumber data penelitian ini berupa dokumen pembelajaran berupa video yang direkam langsung di lokasi penelitian. Jenis video yang diteliti merupakan rekaman pembelajaran membaca permulaan yang diikuti anak usia tiga tahun. Prosedur pengumpulan data dilakukan melalui tiga tahapan. Pertama, melakukan koordinasi dengan kepala unit. Koordinasi dengan kepala unit dilakukan untukmeminta izin dan lamanya waktu penelitian. Kedua, mengamati dan merekam guru dan sis wa ketika kegiatan pembelajaran berlangsung. Perekaman dilakukan ketika guru membuka pelajaran (salam dan doa) hingga kegiatan inti, dan terakhir menutup pelajaran dengan berdoa. Ketiga, melakukan transkripsi rekaman secara keseluruhan berdasarkan video yang diperoleh dari kamera Canon Ixus 145. 
Analisis data dilakukan melalui tiga tahapan, yaitu (1) reduksi data, (2) penyajian data, dan (3) penarikan kesimpulan. Pertama, reduksi data. Pada tahap ini, tuturan-tuturan guru dipilah-pilah sesuai fokus penelitian, sedangkan tuturan yang tidak penting dibuang. Kedua, penyajian data. Pada tahap ini, data yang direduksidisajikan secara naratif. Ketiga, penarikan kesimpulan . Pada tahap ini, ditarik suatu kesimpulan atas suatu fenomena yang telah terjadi di lapangan.

\section{HASIL DAN PEMBAHASAN}

Berdasarkan hasil penelitian, ditemukan wujud apresepsiguru dalam pembelajaran membaca bagi anak usia dini di biMBA AIUEO yang meliputi tiga wujud, yaitu (1) tanya-jawab, (2) analogi, dan (3) bernyanyi. Adapun hasil penelitian ini dibahas sebagaiberikut.

\section{Analogi}

Analogi adalah persamaan atau persesuaian antara dua hal benda atau hal yang berlainan. Analogi digunakan sebagai apersepsibertujuan untuk memahamkan pengetahuan awal siswa. Analogi yang dilakukan guru meliputi (1) analogi menggunakan benda, (2) analogi menggunakan simbol, dan (3) analogi menggunakan media flashcard. Berikut paparan data dan pembahasan penggunaan analogidalam pembelajaran membaca.

Analogi merupakan pengibaratan benda dengan sesuatu atau kesepadanan benda dengan hal lain. Analogi juga dapat diibaratkan simbol lain. Dengan demikian, analogi yang dimaksud adalah pengaitan benda atau simbol lain dengan materi yang akan dipelajari. Penganalogian benda atau simbol lain dapat dilihat pada data berikut.

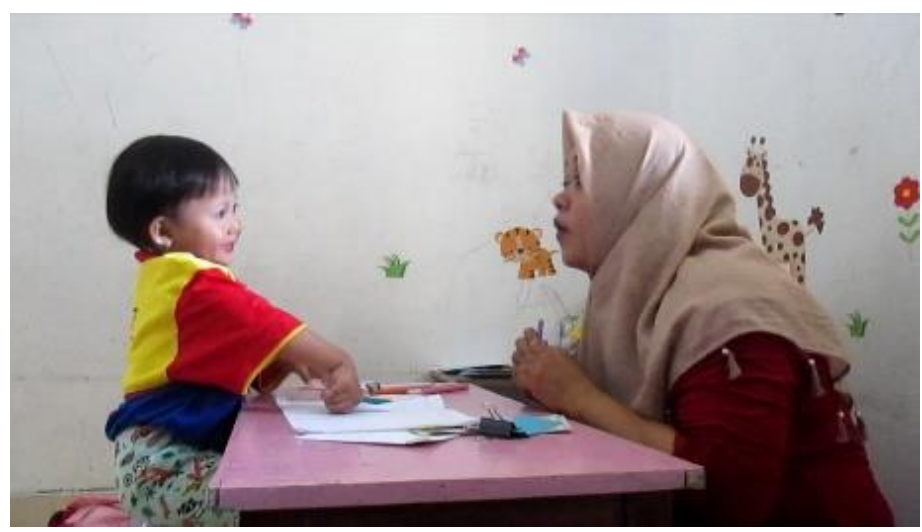

G: ehhh.. pinter. Eh bibi lagi ngapain ya? Bibi lagi ngapain ini? Bibi-nya lagi ngapain ini? [BE] panggil siapa ini namany a? Ini perutny a dua, dip anggil siapa ini? [BE] ... ay o panggilen. [BE].

S: Bee

G: Terus siapa ini y ang kay ak cilok atau donat?

S: $\mathrm{O}$

G: Ihhh.. pinter. Yang ini siapa ya? Siapa ya ini? (menunjuk huruf /B/)

S: (belum merespons hany a memandang guru)

G: Berdiri perutny a dua? (sambil meny anyi) siapa ini namanya?

S: iiii.... aaaa....

G: (geleng-geleng kepala). Ini loh berdiri perutnya dua? (sambil menunjuk siswa) beee

S: beeee

G: ini yang kayak donat, ini siapa?

S: ooooo

G: [be]-[o]- [be]-[o]

S: bobo

G: Jadi, [BE]-[I]-[BE]-[I] bibi. [BE]-[O]- [BE]-[O] bobo. Jadi, bibi lagi? booo

S: booo

G: taruh sini ya! Bibik boooo

S: Booo

Pada pembelajaran ini, siswa diajak membaca satu kalimat sederhana yang terdiri atas dua kata. Kalimat yang akan dibaca, yaitu "bibi bobo" dan "bobi bobo". Untuk itu, siswa hanya diminta mengeja dua kata satu persatu dalam satu kalimat. Kemudian, guru meminta siswa untuk membaca kalimat "bibi bobo". Awalnya, siswa mengeja kata "bibi" dengan melafalkan suku kata bi-bi. Setiap siswa meres pons dengan pelafalan yang tepat, guru memberikan apresiasi berupa pujian dengan menyebut "pinter". Selanjutnya, guru meminta siswa untuk mengeja kata "bobo" dengan melafalkan suku kata bo-bo. Akan tetapi, siswa 
terlihat pasif dalam pembelajaran. Hal itu dapat dilihat ketika siswa enggan atau belum merespons pertanyaan dari guru. Siswa hanya memandang ke arah guru. Ketika guru menanyakan huruf /B/, siswa enggan mere spons. Pada akhirnya guru menyebut secara langsung huruf/B/ dan meminta siswa untuk memanggil huruf/B/. Selanjutnya, ketika siswa enggan merespons, maka guru mengasosiasikan huruf /O/ sebagai cilok atau donat. Setelah itu, guru kembali mengasosiasikan huruf /B/ sebagai berdiri perutnya dua ketika siswa belum merespons. Setelah itu, siswa merespons dengan jawaban yang salah. Kemudian, guru kembali mengasosiasikan huruf /B/ sebagai berdiri perutnya dua ketika siswa merespons dengan jawaban yang salah. Pada akhirnya, gurupun menyebut huruf/B/ diikuti dengan respons siswa. Akhirnya, siswa merespons dengan jawaban yang benar. Ia melafalkan huruf /B/. Kemudian, guru kembali mengasosiasikan huruf/O/ sebagai cilok atau donat. Siswapun segera merespons dengan menjawab /O/. Setelah itu, guru mengeja kata "bobo" diikuti dengan respons siswa yang sama, yaitu "bobo". Guru lalu mengeja kata "bibi", lalu "bobo". Kemudian, guru bertanya aktivitas yang dilakukan bibi dengan pertanyaan "bibi lagi?, lalu guru memberikan pancingan dengan menyebut "bo". Siswapun merespons dengan menyebut "bo". Dengan demikian, guru memberikan apersepsidengan menganalogikan huruf dengan benda dan simbol lain yang mudah diingat. Hal ini sejalan dengan pendapat Harris on \& Coll (2013) yang menyatakan bahwa analogi harus dikenal dan mudah diingat siswa. Dengan demikian, penggunaan analogi yaitu (1) huruf /B/ yang diibaratkan sebagaiberdiri perutnya dua dan (2) huruf/O/ yang diibartakan sebagai cilok atau donat terbukti mampu membuat siswa mengingat konsep atau bentukhuruf /B/ dan/O/. Akhirnya, karena siswa tampak aktif dan mau merespons, maka guru memberikan reward berupa simbol senyum.

Selain dianalogikan dengan benda atau simbol lain, analogi juga dapat menggunakan media flashcard. Flashcard atau media kartu huruf adalah sekumpulan kartu yang salah satu atau di kedua sisinya berisikan kata-kata atau angka maupun gambar yang digunakan untuk melatih siswa membaca. Media kartu huruf (flashcard) yang digunakan guru berbentuk persegi panjang berwarna biru. Berikut ini dipaparkan data apersespianalogi menggunakan media flashcard.

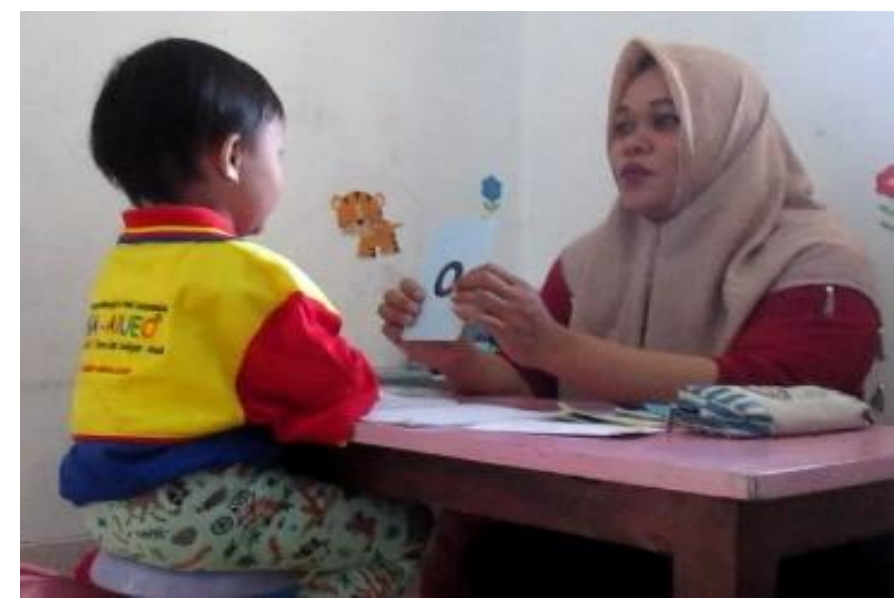

G: berapa ini? Satu, dua, tiga, empat, dan?

S: lima

G: (terus meny anyi lagu "kuberhitung).

G: tanganny a begini. (sambil memegang tangan siswa).

G: doa sebelum belajar ya tuhan berikanlah kami ilmu y ang bermanfaat bagi orangtua dan? Bang? Sa?

Ara: sa

G: amin.

G: ehhh ada ini loh y ang kemarin. Siapa namany a ini? Seperti segitiga itulah huruf?

S: Aaaaa..

G: Pinter sih.

G: Seperti angka satu itulah huruf?

S: Iiii...

G: Ihh, cakep.

G: Seperti ay unan itulah huruf?

S: Uuu...

G: Ihh. Pinter.

G: Seperti sisir Ola itulah huruf?

S: Eee...

G: apa?

S: Eeeeee...

G: Ehh, pinter.

G: seperti kue donat itulah huruf?

S: oooo..

G: Ihh kok bisa seh, tos dulu yuk. Kok bisa seh, kok bisa ya? 
Pada pembelajaran membaca huruf vokal menggunakan media flashcard, guru memperlihatkan media kartu huruf supaya menarik minat siswa dan membangkitkan pengetahuan awal (skemata) sis wa tentang simbol huruf pada kartu yang dipegangnya. Guru memberikan pertanyaan sambil memberikan pentunjukdengan mengasosiasikan huruf-huruf vokal, lalu sis wa diminta untuk menjawab dengan melafalkan huruf pada media tersebut. Pada setiap media kartu huruf tersebut juga terdapat huruf-huruf vokal /A/,/I/, /U/, /E/, dan /O/. Selain itu, juga terdapat gambar di setiap kartu. Akan tetapi, pada pembelajaran kali ini guru hanya menunjuk huruf-hurufnya saja menggunakan jari telunjuk.

Dalam pembelajaran tersebut, guru menggunakan kalimat tanya yang menarik dengan dinyanyikan sehingga menarik minat siswa. Hal itu tampak ketika siswa fokus melihat media huruf /A/ yang dipegang oleh guru. Ketika menanyakan tentang simbol huruf pada media yang dipegangnya, guru bertanya sambil bernyanyi dengan mengasosiasikan huruf-huruf, yaitu /A/ seperti segitiga, huruf /I/ seperti angka satu, huruf /U/ seperti ayunan, huruf /E/ seperti sisir, dan huruf /O/ seperti kue donat. Secara berturut-turut pula, kartu media yang dihadirkan oleh guru terdiri atas huruf /A/,/I/,/U/, /E/, dan/O/. Dengan penggunaan, media ini sis wa tampak semangat dan merespons setiap pertanyaan yang diajukan guru. Sis wa merespons pertanyaan guru dengan jawaban yang benar semua. Siswa secara melafalakan huruf /A/,/I/,/U/, /E/, dan/O/. Dengan demikian, penggunaan media visual berupa flashcard mampu membuat siswa mengingat konsep atau bentuk huruf vokal AIUEO. Arsyad (2011) menyatakan media visual dapat memperlancar pemahaman dan memperkuat ingatan. Hal ini terbukti karena siswa dapat mengingat konsep bentuk huruf vokal AIUEO dengan melafalakan huruf /A/,/I/, /U/, /E/, dan /O/.

Pada pembelajaran membaca huruf konsonan menggunakan media gambar, setelah diperlihatkan media kartu hurufhuruf vokal. Pembelajaran terus berlanjut, hingga sampailah pada materi huruf konsonan. Pada kegiatan ini, guru memperlihatkan media huruf konsonan, yaitu /B/, /D/, /G/. Meski media tersebut memiliki gambar, guru hanya menunjuk huruf-hurufnya saja menggunakan jari telunjuk. Berikut ini dipaparkan kutipan data tersebut.

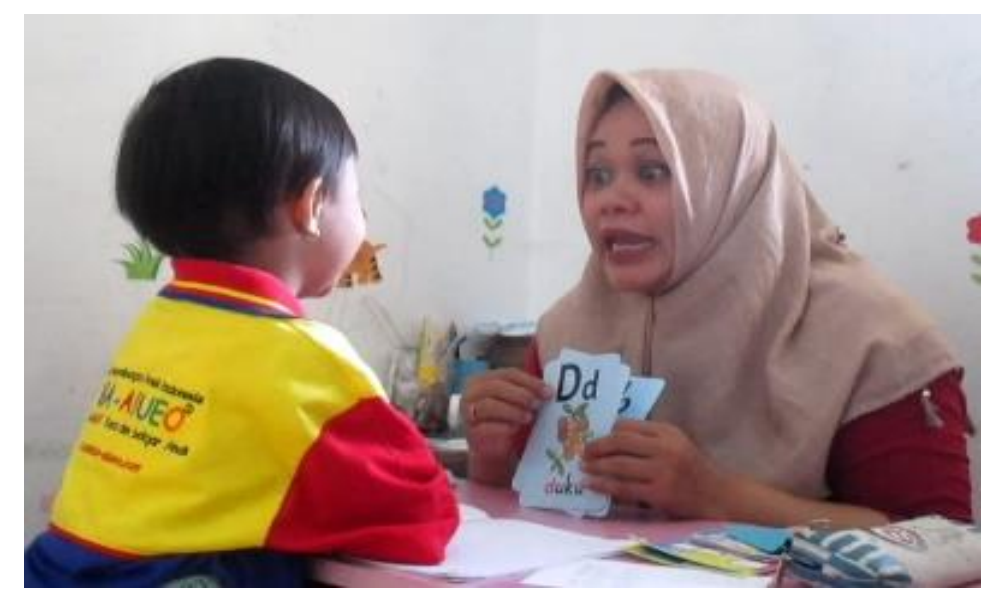

G: Kalau y ang ini bisa gak ya? Ini siapa ya? Berdiri perutnya dua?

S: Iii... Aaaaa..

G: beee... berdiri perutny a dua?

S: beeee...

G: Berdiri perutnya satu?

S: (belum merespons masih lupa atau bingung)

G: Ddeeee

S: Dddeeee.

G: berdiri ehh gak berdiri deh yang ini. Melengkung lalu ke dalam?

$\mathrm{S}$ : (belum merespons masih lupa atau bingung)

G: geee...

S: geeee...

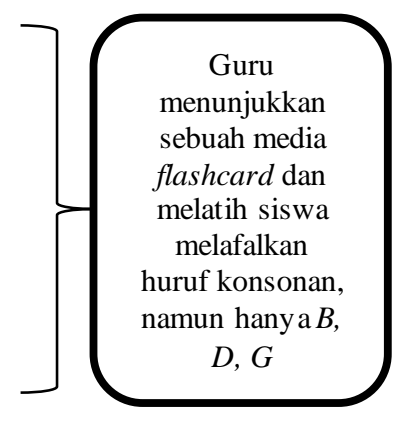

Dalam penggunaannya, mirip seperti kegiatan membaca huruf vokal, namun kali ini guru memperlihatkan huruf konsonan. Guru memperlihatkan media kartu huruf tersebut kepada siswa, lalu guru bertanya dengan petunjuk, yaitu mengasosiasikan huruf-huruf konsonan dengan dinyanyikan kepada siswa. Huruf/B/ diasosiasikan sebagai "berdiri perutnya dua", sedangkan huruf /D/ diasosiasikan sebagai "berdiri perutnya satu", dan huruf /G/ diasosiasikan sebagai "melengkung lalu ke dalam”. Selanjutnya siswa merespons dengan melafalkan huruf pada media yang dipegang oleh guru.

Berbeda dengan sesisebelumya, kali ini siswa menjawab dengan salah. Ketika diperlihatkan media kartu huruf/B/ siswa merespons dengan jawaban yang salah, yaitu /I/ lalu /A/. Padahal guru bertanya dengan memberikan petunjuk dengan mengasosiasikan huruf/B/ sebagai "berdiri perutnya dua". Dengan segera, guru memberikan balikan dengan memberitahu siswa /B/ lalu mengulangi pertanyaannya sekali lagi. Akhirnya, siswapun merespons dengan jawaban yang benar. Kali ini ia menjawab 
/B/. Ketika diperlihatkan media huruf /D/, siswa tidak merespons. Padahal guru bertanya dengan memberikan petunjuk dengan mengasosiasikan huruf/D/ sebagai "berdiri perutnya satu”. Mungkin siswa masih bingung dan mengingat-ingat simbol huruf /D/. Dengan segera, guru memberitahu siswa/D/, namun tidak mengulangi pertanyaannya lagi. Siswapun juga merespons dengan jawaban /D/. Situasi yang sama terjadi ketika diperlihatkan media huruf/G/, siswa juga tidak merespon s pertanyaan guru. Padahal guru bertanya dengan memberikan petunjuk dengan mengasosiasikan huruf/G/ sebagai “melengkung lalu ke dalam”. Mungkin siswa masih bingung dan mengingat-ingat simbol huruf/G/. Selanjutnya, guru memberitahu siswa dengan menyebut secara langsung huruf/G/, namun tidak mengulangi pertanyaannya lagi. Siswapun juga merespons dengan jawaban /G/.

\section{Tanya-Jawab}

Melakukan tanya-jawab merupakan kegiatan apersepsi yang mendorong anak mengungkapkan pendapat atau gagasannya dan membuat anak berpikir. Tanya jawab pada pembelajaran digunakan sebagai apersepsi bertujuan untuk menyiapkan psikologis dan membangkitkan pengetahuan atau pengalaman siswa. Untuk menarik perhatian dan memotivasi siswa untuk berpartisipasi dalam pelajaran, para guru harus mengarah mencoba dengan berbagai pende katan melalui meningkatkan rasa ingin tahu atau menunjukkan perilaku antusias siswa (Richardson, 1996). Siswa yang termotivasi dan peduli akan menunjukkan hasrat, semangat tinggi, dan kecepatan mereka menanggapi pertanyaan setiap guru. Salah satunya yang dilakukan guru bimba AIUEO ialah melakukan tanya-jawab. Tanya-jawab yang dilakukan oleh guru bimba AIUEO dalam pembelajaran membaca permulaan meliputi (1) tanya-jawab materi lama atau sebelumnya dan (2) tanya-jawab materi baru. Berikut paparan data dan pembahasan penggunaan tanya-jawab dalam pembelajaran membaca.

Pertama, tanya jawab materi sebelumnya. Tanya-jawab materi sebelumnya bertujuan untuk mengingatkan kembali pengetahuan atau pengalaman yang siswa miliki. Astiani \& Sukarna (2015) dengan adanya apersepsidengan mengaitkan materi sebelumnya dapat memberikan penguatan kepada siswa. Tanya jawab materi sebelumnya dalam pembelajaran membaca permulaan dapat dilihat pada data berikut.

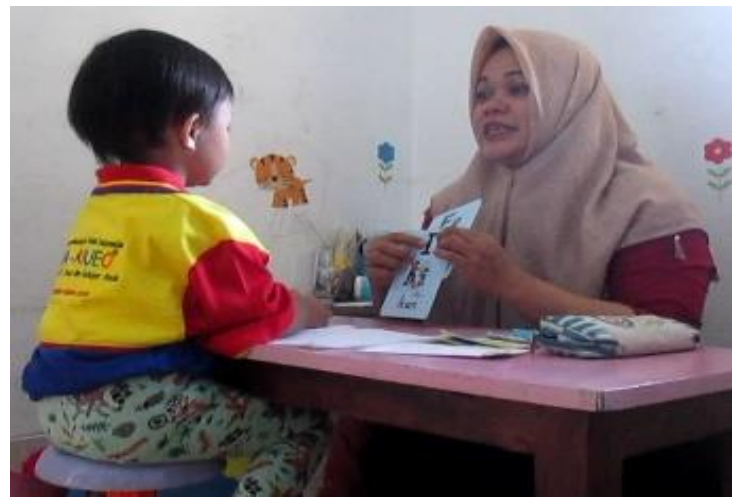

G: berapa ini? Satu, dua, tiga, empat, dan?

S: lima

G: (terus meny anyi lagu "kuberhitung).

G: tanganny a begini. (sambil memegang tangan siswa).

G: doa sebelum belajar y a tuhan berikanlah kami ilmu y ang bermanfaat bagi orangtua dan? Bang? Sa?

Ara: sa

G: amin.

G: ehhh ada ini loh y ang kemarin. Siapa namany a ini? Seperti segitiga itulah huruf?

S: Aaaaa.

G: Pinter sih.

G: Seperti angka satu itulah huruf?

S: Iiii...

G: Ihh, cakep.

G: Seperti ay unan itulah huruf?

S: Uuu...

G: Ihh. Pinter.

$\mathrm{G}$ : Seperti sisir Ola itulah huruf?

S: Eee...

G: apa?

S: Eeeeee...

G: Ehh, pinter.

G: seperti kue donat itulah huruf?

S: oooo..

G: Ihh kok bisa seh, tos dulu yuk. Kok bisa seh, kok bisa ya?

Guru

menunjukkan

sebuah media

flashcard dan menunjukan huruf vokal,

y aitu $A, I, U, E, O$

y ang sudah

dipelajari sebelumny a 
Guru menanyakan materi pada pertemuan selanjutnya tentang konsep huruf vokal. Cara ini terbukti ampuh untuk membangkitkan ingatan atau pemahaman siswa. Ahmad, Tambak, \& Constantiani(2017) menyatakan bahwa tanya jawab adalah suatu cara mengajar yang menimbulkan umpan balik antara guru dan siswa dalam pembelajaran dengan cara memberikan suatu pertanyaan sehingga dijawab oleh siswa. Dengan demikian, tanya-jawab materi sebelumnya dapat mempersiapkan siswa untuk mengikuti materi padakegiatan pembelajaran yang akan dilakukan. Tanya-jawab yang dilakukan guru menggunakan materi yang akrab dengan kehidupan sehari-hari siswa. Peserta didik akan tertarik dengan penyampaian apersepsi kehidupan sehari-hari atau lingkungan sekitar peserta didik Oleh karena itu, peserta didik akan terus mmengikuti proses pembelajaran. Kedua, tanya-jawab materi baru. Dalam apersepsi ini, tanya jawab bukan hanya terkait materi sebelumnya, namun juga terkait materi baru. Supaya dapat menyajikan pelajaran baru, guru membuat representasi logis dengan menghubungkan bahan pelajaran baru dengan yang materi sebelumnya yang sudah dipahami oleh siswa melalui tanya-jawab. Hal ini dapat dilihat pada kutipan data berikut.

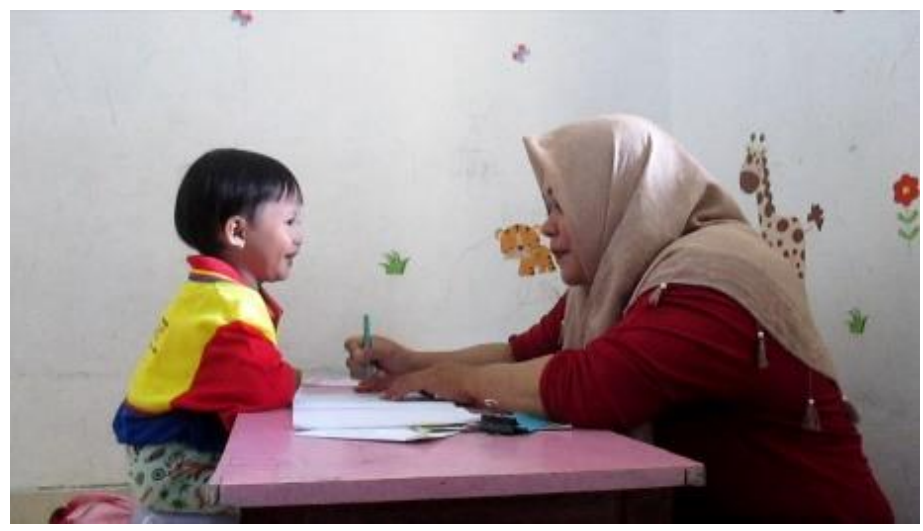

G: Ini siapa namany a? Siapa namanya?

S: beee

G: Pinter. Ini siapa namanya?

S: Aaaaa

G: yang ini kamu belum tahu, bunda kasih tahu ya? Ini namanay a /J/?

S: jeee

G: seperti gagang payungitulah huruf /J/ (sambil menyayi)

S: jeee

G: kamu pernah puny a pay ungkan? Payung itukan gini ya?

S: pay ung kuping

G: Pay ungny a ada kupingny a gini ya? Terus ini ada gagang payungy a ya? (sambil menggambar payung)

G: Namany a siapa ada gagang payungnya?

S: tapi ada matanya.

G: Ampun miss era. Senyum gak? Ada bibirnya.

S: (mengangguk)

G: hah? Pay ungny a ola di sini. Ini siapa ada gagang payung?

$S$ : (belum merespons)

G: Namany a huruf? Jeee

S: Jeeee (sambil menghentak-hentakkan tangan di meja).

G: [BE]-[A]- [JE]. Ini siapa ini? Siapa la?

S: bintang (menunjuk halaman sebelumny a di buku tulis)

G: belum ditarikin garis? Sek-sek lupa miss era y a lupa dikasih bintang y ang besar ya. Warnany a apa? Hijau?

S: (mengangguk)

G: eh kuning aja

$\mathrm{S}:$ (menunjuk pensil hijau)

G: eh hijau aja. [HA]-[I]-[JE]-[A]-[U]?

G \& S: hijau.

G: kasih bintang yang besar sekali ya (sambil menggambar bintang dengan ukuran besar). Aduh bapaknya seneng ini. Ini juga yakasih bintang. Kasih hijau? Warna merah atau kuning?

S: kuning

G: [KA]-[U]-[EN]-[I]-[ENG]?

$\mathrm{G} \& \mathrm{~S}$ : kuning.

G: wow bintangny a ada berapa? Satu... dua...

Siswa: Oren (sambil menunjuk pensil warna oranye)

G: oren di sini kalau sudah penuh kita kasih di sini ya oke (sambil menujuk halaman sebelumnya di buku tulis siswa).

Guru melakukan tanya-jawab terkait materi baru y ang akan dipelajari, y aitu huruf "J" 
Pada pembelajaran ini, ketika siswa diminta membaca kalimat "baju”. Guru bertanya sambil menunjuk huruf/B/. Siswa langsung merespons dengan jawaban yang tepat. Ia melafalkan huruf /B/ karena merespons dengan benar, guru memberikan apresiasi dengan memuji siswa pinter. Setelah itu, Guru bertanya sambil menunjuk huruf/A/. Sis wa langsung merespons dengan jawabaan yang tepat. Ia melafalkan huruf /A/. Akan tetapi, siswa belum dikenalkan huruf /J/. Pada pembelajaran kali ini siswa dikenalkan huruf yang baru dikenalnya, yaitu huruf /j/. Supaya bisa membaca huruf /J/, siswa diberi petunjuk huruf /J/ sebagai gagang payung sambil dinyanyikan. Siswapun merespons dengan jawaban yang tepat dengan melafalkan huruf /J/. Selanjutnya guru dan sis wa berdialog tentang payung. Guru menanyakan pengetahuan siswa tentang payung. Sis wa merespons bahwa payung memiliki kuping. Selanjutnya, guru menggambar payung. Selanjutnya, guru menanyakan huruf yang memiliki gagang payung. Guru ingin siswa menyebut /J/. Akan tetapi, siswa meminta guru menggambar mata pada gambar payung. Kemudian, guru meminta persetujuan siswa untuk menggambar simbol senyum dan bibir pada gambar payung.

Siswa hanya mengangguk saja. Guru lalu bertanya tentang huruf yang ada gagang payung. Akan tetapi, siswa belum merespons. Guru bertanya lagi, namun ia langsung menyebut huruf /J/. Sis wapun langsung merespon s dengan melafalkan huruf /J/. Siswa tampak senang sekali karena berhasil melafalkan huruf /J/. Bahkan, ia menghantam-hantamkan tangan ke meja. Guru lalu mengeja kata /B-/A/-/J/ dengan tujuan siswa akan melafalkan /U/. Akan tetapi, siswa malah meminta simbol bintang untuk pekerjaan pertemuan sebelumnya padahalaman sebelumnya. Akhirnya, guru membuat garis untukmembentuk gambar bintang. Sebelum itu, guru meminta persetujuan siswa bahwa ia akan menggunakan pensil warna hijau. Siswapun merespon s dengan hanya mengangguk. Setelah itu, guru menggoda siswa antara menggunakan pensil warna hijau dan kuning. Ketika siswa menunjuk pensil warna hijau, guru mengeja kata /H/-/I/-/J/-/A/-/U/.

Guru dan siswa bersama-sama menyebut "hijau". Setelah itu, guru memberikan pernyataan dan menggambar bintang dengan ukuran yang besar. Selanjutnya, guru bertanya tentang pensil warna yang akan digunakan. Guru hanya memberikan opsi hijau atau kuning. Untuk itu, siswa memilih warna kuning. Alhasil, ia merespons dengan menyebut kuning. Oleh karena itu, guru mengeja /K/-/U/-/N/-/I/-/N/-/G/. Ternyata, sis wa merespons dengan menjawab kuning diikuting oleh respons yang sama oleh guru, yaitu "kuning". Guru lalu menanyakan jumlah bintang yang ditulisnya. Ia memberi pernyataan satu-dua. Sis wa merespons dengan mengatakan "oren" sambil menunjuk pensil warna oranye. Selanjutnya, guru memberikan balikan bahwa akan memberi bintang pada halaman selanjutnya apabila sudah penuh.

\section{Bernyanyi}

Bernyanyi merupakan kegiatan melantunkan sebuah lagu. Kegiatan ini bertujuan untuk menyampaikan pesan dan membuat tenang serta nyaman bagi siswa. Kegiatan bernyanyi yang dilakukan guru oleh guru ialah melantunkan lagu BDGKMPSY. Aminah (2016:185) menyatakan nyanyian, lagu, maupun musik merupakan dunia anak. Oleh karena itu, apersepsi dilakukan dengan menyanyikan sebuah lagu sangat cocok dilakukan untuk anak. Apersepsi dengan melantunkan lagu BDGKMPSY dengan panduan guru dapat dilihat pada data berikut.

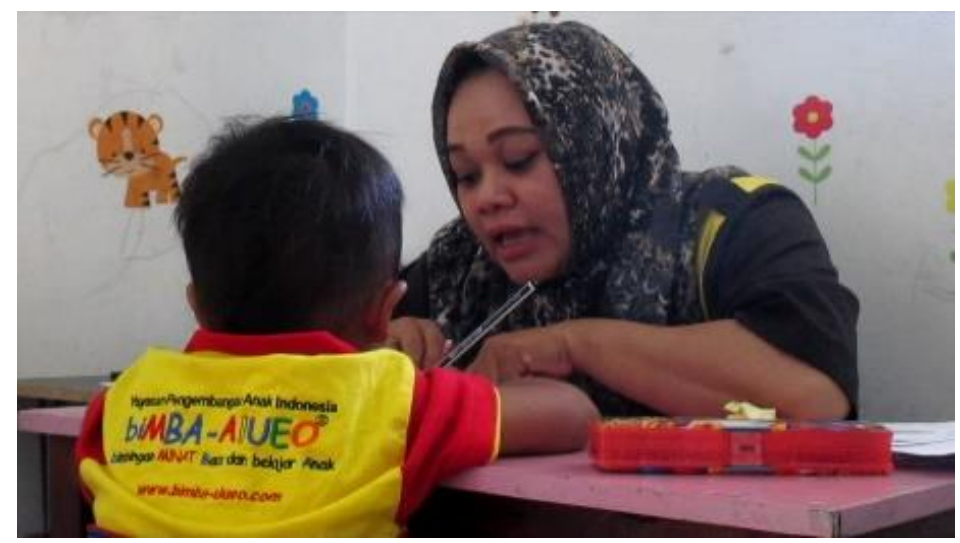

Bunda Era: Daaaguuu.. kalau ini namany a apa ini? /G/-/I/-/G/-/I/? (sambil meny anyi)

Azril: gigi.

Bunda Era: gigi. Coba seh dibaca ini?

Azril: Peeee... aaaa...

Bunda Era: Beee.. Deee.. Geee (sambil meny anyi)

Bunda Era \& Azril: tok

Bunda Era: Beee.. Deee.. Geee tok.. Kaaaa... Eeem... Peee.. eees....y eee... yey ey eye. (sambil meny anyi)

Azril: yeeyeyey

Bunda Era: Beee.. Deee (sambil menyanyi)

Azril: geee

Bunda era: berarti ini namanya apa?

Azril: geee

Guru memandu siswa meny anyi lagu BDG-

KMPSY ketika

siswa lupa

konsep huruf 
Berdasarkan paparan tersebut, ketika siswa lupa konsep huruf "G", guru melantunkan sebuah lagu supaya siswa mengingat kembali huruf "G". Pancingan dengan menyanyi semacam ini terbukti ampuh sehingga siswa mampu mengingat dan melafalkan huruf "G'. Dalam lirik lagu yang dinyanyikan guru terdapat susunan huruf-huruf yang membantu siswa mengenali atau mengingat huruf. Selain data tersebut, apersepsi dengan melantunkan lagu BDG-KMPSY dengan panduan guru dapat dilihat pada data berikut.

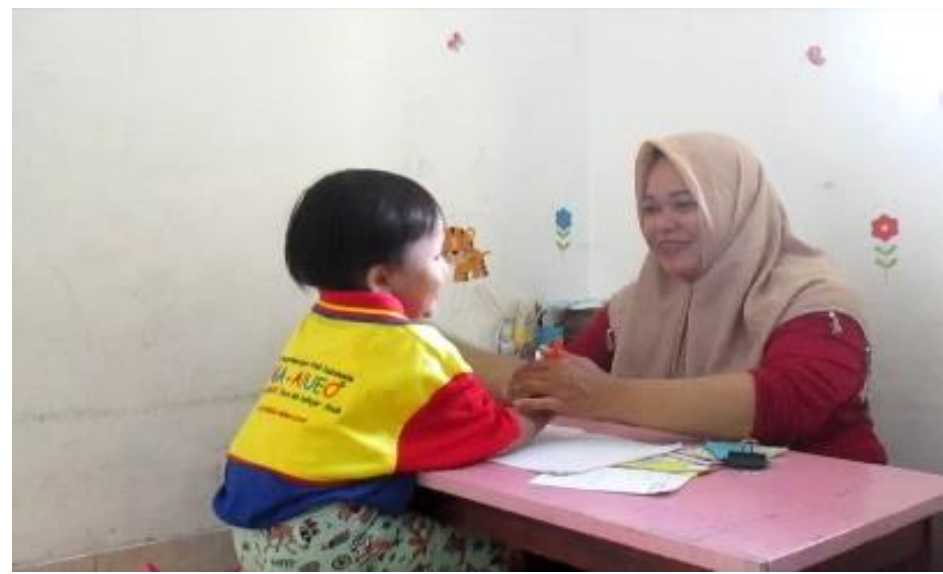

G: yang ini yuk! (lalu meny anyi). Beee.. Deee...Gee.. tok.. Beee.. Deeee... Geee.. tok... Kaaaempeesye y ey ey eye. Sekarang kita mau ke [Be]. B-nya ke mana ya? B-nya Ola kemana ya? Miss Era bikinin ya? Mau warna biru, pink, atau oranye atau hijau?

Ola: Mau y ang ini.

$\mathrm{G}$ : apa ungu?

Ola: mau ini (sambil mengangkat pensil warna pink).

G: Itu warnany a apa? Pink.

Ola : pink.

G: Miss Era tulisin ya. Nyanyiin ya! (menyanyi) Beee.. Deee...Gee.. tok.. Beee.. Deeee... Geee.. tok... Kaaaempeesye yeyeyeye. Nyanyiin seh Beee.. Deee...Gee.. tok.. Beee.. Deeee... Geee.. tok... Kaaaempeesye yey ey eye . Ayo nyanyikan! Beee.. Deee...Gee.. tok.. Beee.. Deeee... Geee.. tok... Kaaaempeesye yeyeyeye

Ola: Yeyeyeye

G: Yeee.. ayo lagi dengerin. Ayo ny anyi (sambil menunjukkan huruf B pada buku tulis siswa). BDG tok. Nyanyi lagi (sambil memegang tangan siswa agar mau menunjuk huruf B) Panggil ini. BDG tok. Lagi-lagi, ay o dilihatin. BDG tok, ay o dilihatin ini. KMPSY.

Ola: Yey eyeye

G: Ihh, pinter. Udah bisa ini.

Pada pembelajaran ini, guru dan siswa secara bersama-sama menyanyi lagu BDG-KMPSY. Ketika menyanyi, secara bergantian guru memperlihatkan media kartu huruf/B/, /D/, /G/ yang dipegangnya. Selesai bernyanyi, guru menyimpan ketiga media kartu huruf tersebut. Pembelajaran berlanjut dengan guru dan siswa menyanyi lagu BDG-KMPSY tanpa media kartu huruf. Dengan demikian, pembelajaran berlangsung tanpa menggunakan media kartu huruf. Kemudian, guru memberi pilihan kepada siswa tentang pensil warna yang akan digunakannya. Dengan segera, siswa merespon dengan menjawab secara verbal sambil memegang pensil warna pink. Dengan demikian, siswa memilih pensil berwarna pink untuk digunakan oleh guru. Sekanjutnya, guru menunjuk huruf /B/, /D/, /G/ /K/ /M//P//S//Y/ yang ditulisnya pada buku tulis siswa. Kemudian, Guru seca ra berurutan menunjuk huruf-huruf yang ditunjuk secara berurutan /B/, /D/, /G/ /K/ /M/ /P/ /S/ /Y/ dengan cara dinyanyikan. Pada kegiatan ini guru mengajak siswa menyanyi lagu "BDG-KMPSY" dengan bantuan tulisan tangan. Guru menyanyi dengan nyaring sekali, namun tidak diikuti dengan siswa. Meski guru sudah memberikan perintah agar siswa ikut menyanyi, tapi siswa kurang merespon. Siswa hanya merespon pada lirik terakhir, yakni "yeyeyeye". Dengan demikian, siswa menyebut huruf terakhir saja, yaitu /Y/. Tampaknya, siswa tidak hafal lirik lagu tersebut. Dengan demikian, anak menunjukkan bahwa ia menyukai stimulasi melalui lagu. Hal ini juga ditemukan pada temuan lain. Temuan Rosmiati, (2014) menunjukkan bahwa aelalui irama musik dengan menyanyikan lirik, maka anak akan merespon secara positif. Oleh karena itu, stimulasi melalui lagu atau nyanyian cocok untuk menstimulasi anak dalam belajar membaca sambal bernyanyi. 


\section{SIMPULAN}

Simpulan penelitian ini memiliki tiga simpulan wujud apersepsiguru. Pertama, menggunakan analogi. Analogi yang dilakukan oleh guru, meliputi (1) analogi menggunakan media flashcard,(2) analogi menggunakan benda dan atau simbol. Kedua, melakukan tanya-jawab. Tanya-jawab yang dilakukan oleh guru meliputi tanya-jawab materi lama atau sebelumnya dan tanyajawab materi baru. Ketiga, melakukan kegiatan bernyanyi. Kegiatan bernyanyi yang dilakukan guru menggunakan lagu BDGKMPSY.

Saran ditujukan kepada beberapa pihak demi perbaikan kualitas pembelajaran membaca permulaan. Oleh sebab itu, terdapat saran-saran yang ditujukan kepada guru. Pertama, hendaknya guru tetap dapat menggunakan ketiga kegiatan apersepsi sehingga pembelajaran terasa menyenangkan bagi anak dan sesuaidengan kebutuhan dan perkembangannya. Kedua, hendaknya guru lebih mengoptimalkan kegiatan apersepsi karena dalam beberapa hal siswa tidak merespon. Ketiga, hendaknya guru dapat mengembangkan variasi apersepsi dalam kegiatan pembelajaran atau dengan media yang bervariasi.

\section{DAFTAR RUJUKAN}

Ahmad, M. Y., Tambak, S., \& Constantiani, N. (2017). Hubungan Metode Tanya Jawab dengan Minat Belajar Peserta Didik pada Mata Pelajaran Pendidikan Agama Islam. Jurnal Pendidikan Agama Islam Al-Thariqah, 2(1), 89. https://doi.org/10.25299/althariqah.2017.vol2(1).650

Aminah, M. E. (2016). Strategi Mengusik (Mengeja dengan Musik) sebagaiCara Cepat Belajar Membaca Permulaan di Sekolah Dasar. Jurnal Al Bidayah, 8(2), 185-194.

Asiah, N. (2018). Pembelajaran Calistung Pendidikan Anak Usia Dini dan Ujian MasukCalistung Sekolah Dasar di Bandar Lampung. Terampil : Jurnal Pendidikan dan Pembelajaran Dasar, 5(1), 19. https://doi.org/10.24042/terampil.v5i1.2746

Astiani, R., \& Sukarna, I. M. (2015). Pengembangan Video Apersepsi Konfigurasi Elektron dan Hubungannya dengan Tabel Periodik Unsur Kelas X SMA/MA. Jurnal Pembelajaran Kimia, 7(2), 87-95.

Azhar Arsyad, M. (2011). Media Pembelajaran. Jakarta: Rajawali.

Bellucci, F. (2015). Logic, Psychology, and Apperception: Charles S. Peirce and Johann F. Herbart. Journal of the History of Ideas, 76(1), 69-91. https://doi.org/10.1353/jhi.2015.0007

Brdar, I., Rijavec, M., \& Loncaric, D. (2006). Goal Orientations, Coping with School Failure and School Achievement. European Journal of Psychology of Education, 21(1), 53-70. https://doi.org/10.1007/BF03173569

Brew, A., \& Boud, D. (1995). Teaching and Research: Establishing the Vital Link with Learning. Higher Education, 29(3), 261-273. https://doi.org/10.1007/BF01384493

Churiyah, Y. (2013). Pendidikan Bahasa dan Sastra Indonesia di Sekolah Dasar Kelas Rendah. Jakarta: Departemen Pendidikan dan Kebudayaan.

Etikawati, A. I. (2017). Apersepsi Mengenai Figur Ayah dan Ibu pada Anak-Anak di Yogyakarta. Jurnal Penelitian, 17(2), 7890.

Harrison, A. G., \& Coll, R. K. (2013). Analogi dalam Kelas Sains. Jakarta: Indeks.

Howard, J. (2002). Eliciting Young Children's Perceptions of Play, Work and Learning Using the Activity Apperception Story Procedure. Early Child Development and Care. https://doi.org/10.1080/03004430214548

Ikawati, E. (2013). Upaya Meningkatkan Minat Membaca pada Anak Usia Diniada Anak Usia Dini. Logaritma, I(02), 1-12.

Juel, C., Hall, A., Leavell, J., \& Schneider, D. R. (1988). Learning to Read and Write: A Longitudinal Study of 54 Children from First. Journal of Educational Psychology, 80(4), 437-447.

Lam, S. fong, Cheng, R. W. yi, \& Ma, W. Y. K. (2009). Teacher and Student Intrinsic Motivation in Project-Based Learning. Instructional Science. https://doi.org/10.1007/s 11251-008-9070-9

Miller, E. J. W. (2003). Teaching Methods, the Herbartian Revolution and Douglas Clay Ridgley at Illinois State Normal University. Journal of Geography, 102(3), 110-120. https://doi.org/10.1080/00221340308978532

Mizuno, K., Tanaka, M., Fukuda, S., Imai-Matsumura, K., \& Watanabe, Y. (2011). Relationship Between Cognitive Function and Prevalence of Decrease in Intrinsic Academic Motivation in Adolescents. Behavioral and Brain Functions. https://doi.org/10.1186/1744-9081-7-4

Ningsih, \& Mastuti, S. E. (2013). Perbedaan Pengaruh Pemberian Apersepsiterhadap Kesiapan Belajar Siswa Mata Pelajaran IPS Kelas VII A. Jurnal Pendidikan dan Pembelajaran, 2(6), 1-11.

Palis oa, N. (2008). Strategi Advance Organizer dalam Pembelajaran Kimia. Jurnal Pendidikan "Jendela Pengetahuan.

Pertiwi, A. D. (2016). Study Deskriptif Proses Membaca Permulaan Anak Usia Dini. Jurnal Pendidikan Anak,5(1), 757-762.

Rahyubi, H. (2012). Teori-Teori Belajar dan Aplikasi Pembelajaran Motorik Deskripsi dan Tinjauan Kritis. Bandung: Nusa Media.

Richardson, V. (1996). The Role of Attitudes and Beliefs in Learning to Teach. In Handbook ofResearch on Teacher Education. New York: Macmillan.

Rosmiati, A. (2014). Teknik Stimulasi dalam Pendidikan Karakter Anak Usia Dini melalui Lirik Lagu Dolanan. Resital: Jurnal Seni Pertunjukan, 15(1), 71-82. https://doi.org/10.24821/resital.v15i1.801

Stanovich, K. E. (1986). Matthew Effects in Reading: Some Consequences of Individual Differences in the Acquisition of Literacy. Reading Research Quarterly, 21(4), 360-407. https://doi.org/10.1598/rrq.21.4.1 
Sugahara, S., Sugao, H., Dellaportas, S., \& Masaoka, T. (2016). The Effect of Body-Movement Teaching, Learning Motivation and Performance. Meditari Accountancy Research, 24(3), 414-437. https://doi.org/10.1108/MEDAR-02-2015-0006

Tajuddin, Y. (2018). Belajar Membaca bagi Anak Usia Dini: Stimulasi Menumbuhkan Minat Baca Anak. Thufula: Jurnal Inovasi Pendidikan Guru Raudhatul Athfal,2(1), 127-147. https://doi.org/10.21043/thufula.v2i1.4269

Wilhelm, J., \& Smith, M. W. (2006). What Teachers Need to Know about Motivation. Voices from the Middle, 13 (4), 29.

Williams, R. L., \& Stockdale, S. L. (2004). Classroom Motivation Strategies for Prospective Teachers. Teacher Educator, 39(3), 212-230. https://doi.org/10.1080/08878730409555342 